\title{
PEMETAAN DAERAH POTENSI LONGSOR DI KABUPATEN TRENGGALEK MENGGUNAKAN DATA CITRA SATELIT MULTI-TEMPORAL
}

\author{
Bustam Fiqor Maulana ${ }^{1}$, Muhammad Taufik ${ }^{2}$ \\ ${ }^{1,2}$ Departemen Teknik Geomatika, FTSLK-ITS, Kampus ITS Sukolilo, Surabaya, 60111, Indonesia \\ e-mail: 2taufik_m@geodesy.its.ac.id
}

\begin{abstract}
Abstrak
Penggunaan tiga data citra satelit pada lokasi yang sama dan waktu yang berbeda yaitu 2003, 2013, dan 2018, menghasilkan tiga peta potensi longsor dengan seri waktu yang berbeda yaitu tahun 2003, 2013, dan 2018. Peta potensi longsor yang dihasilkan diklasifikasi dalam tiga kelas tingkat potensi longsor. Hasil dari peta potensi longsor menunjukkan terdapat perbedaan luasan kelas tingkat potensi. Dalam rentang waktu tahun 2003 sampai tahun 2013 terdapat total perubahan luasan kelas tingkat potensi sebesar $10082.25 \mathrm{Ha}$. dari total seluruh luas Kabupaten Trenggalek. Pada rentang waktu 2013 sampai tahun 2018 terdapat perubahan sebesar 14882.77 Ha. Perhitungan korelasi antara perubahan luasan tutupan lahan dengan perubahan potensi longsor bernilai +1 . Nilai ini menunjukkan adanya korelasi positif yang sangat kuat antara perubahan luasan zona potensi longsor dengan perubahan luasan tutupan lahan.
\end{abstract}

Kata Kunci: Potensi Tanah Longsor, Sistem Informasi Geografis, Citra Satelit Multi-temporal, Skoring

\begin{abstract}
The use of three satellite imagery data at the same location and different time are 2003, 2013 and 2018, resulting in three potential maps of landslide with different time series of 2003, 2013, and 2018.. Map of potential landslides generated classified in three classes of potential landslide levels. The result of a potential landslide map indicates there is a difference in potential level classes. In the span of years 2003 to 2013 there was a total change in the class of potential levels of 10082.25 hectares of the total area of Trenggalek Regency. From 2013 to 2018 there were a change of 14882.77 hectares. Calculation of correlation between land cover area change with potential landslide change is equal +1 . This value indicates a very strong positive correlation between changes in the area of landslide potential with the change in land cover.
\end{abstract}

Keywords: Potentential Landslide, Geographic Information System, Multi-temporal Satellite Imagery Data, Scoring 


\section{PENDAHULUAN}

Tanah longsor merupakan pergerakan masa tanah atau batuan atau campuran dari keduanya yang keluar dari kelerengan tanah akibat adanya gangguan dari kestabilan tanah atau batuan penyusun lereng. Penyebab utama longsor adalah air yang meresap hingga mencapai lapisan tanah kedap air. Penambahan beban tanah diatas bidang gelincir yang tidak dapat menahan beban terbut sehingga memicu pergerakan tanah. Kejadian bencana tanah longsor menyebabkan kerusakan dan kerugian baik dalam bentuk materi maupun jiwa (PVMBG, 2005). Perubahan topografi lahan dari dampak tanah longsor mempengaruhi kehidupan masyarakat yang hidup di lahan tersebut. Sebab dari itu, penelitian untuk inventarisasi daerah rawan longsor diperlukan agar di kemudian hari tidak terdapat penambahan korban yang lebih banyak (Arifin, dkk, 2006).

Kabupaten Trenggalek merupakan salah satu daerah di Provinsi Jawa Timur yang sering mengalami bencana. Dalam situs Badan Penanggulangan Bencana Daerah (BPBD) Kabupaten Trenggalek terdapat 153 kejadian bencana sepanjang tahun 2018. Kerugian yang ditimbulkan antara lain 126 rumah rusak ringan, 12 rumah rusak sedang, dan 6 rumah rusak berat. 39 dari angka total kejadian bencana yaitu bencana tanah longsor. Jika ditinjau dari frekuensi bencana tanah longsor sejak tahun 2013 sampai 2017, secara berurutan Kabupaten Trenggalek telah mengalami bencana tanah longsor sebanyak 57, 20, 21, 84 dan 84 kejadian (BPS Kabupaten Trenggalek, 2018).

Citra satelit dari penginderaan jauh merupakan teknologi yang banyak digunakan untuk pemetaan tanah longsor. Dalam penelitian ini digunakan data citra satelit multi temporal wilyah studi kasus pada tahun 2003, 2013, dan 2018. Data citra satelit multi temporal adalah beberapa data citra satelit pada satu lokasi yang masing-masing data citra memiliki waktu yang berbeda (Fanni, 2014). Data citra satelit diolah untuk menghasilkan peta tutupan lahan. Selain data citra satelit multi temporal, penelitian ini juga menggunakan data digital elevation model (DEM), data curah hujan, dan peta jenis tanah. Data DEM diolah untuk menghasilkan peta kelerengan. Data curah hujan diolah untuk menghasilkan peta curah hujan. Peta jenis tanah dlam bentuk raster dikonversi dalam bentuk vektor.

Hasil dari pengolahan data-data tersebut kemudian dilakukan analisis spasial dan pembobotan untuk menghasilkan peta potensi longsor pada tahun 2003, 2013, dan 2018. Analisis spasial dilakukan dengan menggunakan sistem informasi geografis. Bobot dari masingmasing hasil olahan data antara lain peta tutupan lahan dengan bobot $20 \%$, peta curah hujan dengan bobot $20 \%$, peta kelerengan dengan bobot $30 \%$ dan peta jenis tanah dengan bobot $30 \%$. Hasil peta potensi longsor pada tiap tahunnya divalidasi menggunakan data kejadian longsor di Kabupaten Trenggalek (Khoiri, Jaelani, dan Widodo 2017). Kemudian dilakukan analisa perbedaan pada masing-masing peta potensi longsor yang telah divalidasi.

\section{METODOLOGI PENELITIAN}

Lokasi penelitian ini yaitu Kabupaten Trenggalek, Jawa Timur, Indonesia. Kabupaten Trenggalek secara geografis berlokasi pada koordinat $111^{\circ} 24^{\prime}$ hingga $112^{\circ} 11^{\prime}$ bujur timur dan $7^{\circ} 63^{\prime}$ hingga $8^{\circ} 34^{\prime}$ lintang selatan. Kabupaten ini terbagi menjadi 14 Kecamatan dan 157 Desa. Batas administrasi Kabupaten Trenggalek adalah sebagai berikut :

- Utara : Kabupaten Ponorogo dan Kabupaten Tulungagung

- Timur : Kabupaten Tulunagung

- Selatan : Samudra Hindia

- Barat : Kabupaten Ponorogo dan Kabupaten Pacitan

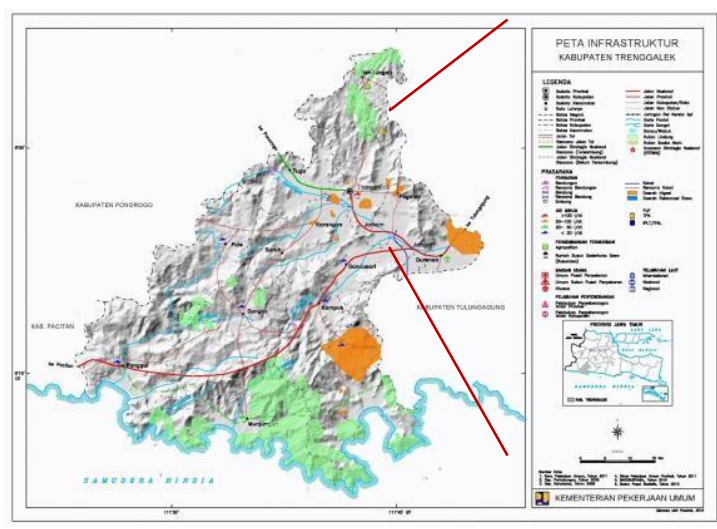

Gambar 1. Lokasi Penelitian (Sumber: Kementerian PUPR 2014) 
Tahapan pengolahan data pada penelitian ini digambarkan dalam diagram alir berikut ini:

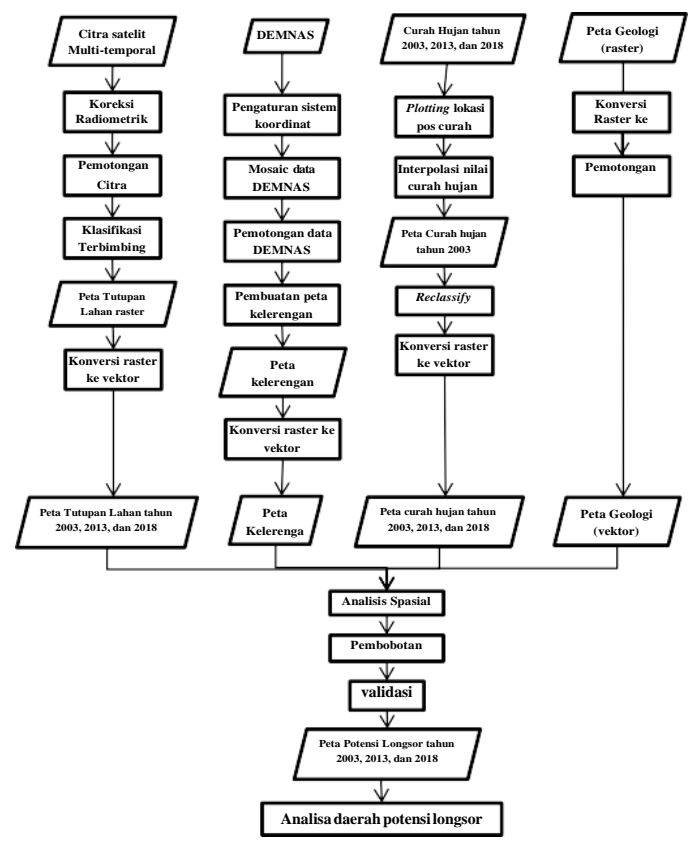

Gambar 2. Diagram Alir Proses Pengolahan Data (Sumber: Hasil Pengolahan)

Data yang digunakan dalam penelitian ini antara lain:

1. Citra satelit multi-temporal dengan rincian :

- Landsat 7 ETM path 119 row 066 tanggal akusisi data 13 Mei 2003

- Landsat 8 OLI/TIRS path 119 row 066 tanggal akuisisi 7 Oktober 2013

- Landsat 8 OLI/TIRS path 119 row 066 tanggal akuisisi 1 Juli 2018

2. Peta batas administrasi wilayah Kabupaten Trenggalek tahun 2012.

3. Curah hujan wilayah Kabupaten Trenggalek pada tahun 2003, 2013 dan 2018 yang diperoleh dari Dinas PU Sumber Daya Air Provinsi Jawa Timur

4. DEMNAS wilayah Kabupaten Trenggalek dengan resolusi spasial 0.27-arcsecond yang diperoleh dari situs DEM Nasional BIG. Data DEMNAS untuk seluruh wilayah Kabupaten Trenggalek terdiri dari beberapa nomor lembar peta antara lain :

- DEMNAS nomor lembar peta 1507-
42

- DEMNAS nomor lembar peta 150744

- DEMNAS nomor lembar peta 150751

- DEMNAS nomor lembar peta 150752

- DEMNAS nomor lembar peta 150753

- DEMNAS nomor lembar peta 150754

- DEMNAS nomor lembar peta 150821

- DEMNAS nomor lembar peta 150822

5. Peta geologi Kabupaten Trenggalek tahun 2009 yang diperoleh dari Dinas ESDM Provinsi Jawa Timur

6. Data kejadian bencana tanah longsor Kabupaten Trenggalek yang diperoleh dari BPBD Provinsi Jawa Timur

Penggunaan ilmu penginderaan jauh digunakan untuk pengolahan data citra satelit, keilmuan SIG digunakan untuk pengolahan data bereferensi geografis dan analisis spasial. Parameter potensi longsor yang telah dihasilkan ditumpang tindihkan dan dihitung tingkat potensi longsornya. Pembobotan dilakukan untuk setiap data yang telah diolah (data tutupan lahan, kelerengan, curah hujan, dan jenis tanah). Setiap data diberi skor masing-masing untuk menentukan nilai akhir potensi longsor. Uraian skor pada setiap data terdapat pada tabel sebagai berikut (Khoiri, Jaelani, dan Widodo 2017).

Tabel 1. Pembobotan parameter potensi longsor (Sumber: Khoiri, Jaelani, dan Widodo 2017)

\begin{tabular}{cccc}
\hline Faktor & \multicolumn{2}{c}{ Kelas } \\
\hline Kelerengan & $30 \%$ & $0 \%-8 \%$ & 1 \\
& & $8 \%-25 \%$ & 2 \\
& & $25 \%-40 \%$ & 3 \\
& & $40 \%-100 \%$ & 4 \\
Curah & \multirow{2}{*}{$20 \%$} & $<2000$ & 1 \\
Hujan & & $2000-3000$ & 2 \\
& & $>3000$ & 3 \\
Tutupan & $20 \%$ & Awan & 0 \\
Lahan & & Sungai & 0 \\
& & Pertanian & 1 \\
& & Hutan & 1 \\
\hline
\end{tabular}




\begin{tabular}{|c|c|c|c|}
\hline \multirow{19}{*}{$\begin{array}{c}\text { Litologi } \\
\text { (jenis tanah } \\
\text { dan batuan) }\end{array}$} & & Pemukiman & 1 \\
\hline & & Perkebunan & 2 \\
\hline & $30 \%$ & $\begin{array}{c}\text { Batu } \\
\text { Terobosan }\end{array}$ & 1 \\
\hline & & Batuan & 1 \\
\hline & & $\begin{array}{c}\text { Gunung Api } \\
\text { Wilis }\end{array}$ & \\
\hline & & Formasi Jaten & 1 \\
\hline & & $\begin{array}{c}\text { Formasi } \\
\text { Kabuh }\end{array}$ & 1 \\
\hline & & $\begin{array}{l}\text { Formasi } \\
\text { Mandalika }\end{array}$ & 1 \\
\hline & & $\begin{array}{c}\text { Formasi } \\
\text { Wonosari }\end{array}$ & 1 \\
\hline & & Formasi Wuni & 1 \\
\hline & & Alluviums & 2 \\
\hline & & Endapan & 2 \\
\hline & & Alluvium & \\
\hline & & Morfonit & 3 \\
\hline & & Dangean & \\
\hline & & $\begin{array}{l}\text { Morfonit } \\
\text { Ngebel }\end{array}$ & 3 \\
\hline & & $\begin{array}{l}\text { Morfonit } \\
\text { Sedudo }\end{array}$ & 3 \\
\hline & & $\begin{array}{l}\text { Morfonit } \\
\text { Tanjungsari }\end{array}$ & 3 \\
\hline & & $\begin{array}{c}\text { Morfoset Jeding } \\
\text { Patukbanteng }\end{array}$ & 3 \\
\hline
\end{tabular}

Dilakukan validasi pada hasil operasi analisis spasial dan overlay. Pelaksanaan validasi dilakukan dengan menggunakan datakejadian longsor di Kabupaten Trenggalek. Kemudian dilakukan analisis perubahan daerah potensi longsor dan analisis korelasi antara perubahan tutupan lahan dengan daerah potensi longsor. perhitungan korelasi menggunakan rumus korelasi berikut.

Koefisien korelasi $=\frac{\Sigma(\mathrm{X}-\overline{\mathrm{X}})(\mathrm{Y}-\overline{\mathrm{Y}})}{\sqrt{\Sigma(\mathrm{X}-\overline{\mathrm{X}})^{2}}(\mathrm{Y}-\overline{\mathrm{Y}})^{2}}$

Keterangan:

$X=$ nilai variabel

$X Y=$ nilai variabel $Y$

$\bar{X}=$ rata- rata nilai variabel $X$

$\bar{Y}=$ rata- rata nilai variabel $Y$

\section{HASIL DAN PEMBAHASAN}

\section{Pengolahan Parameter Potensi Longsor}

Citra satelit multi-temporal adalah Penggunaan beberapa data citra satelit pada lokasi yang sama dengan waktu yang berbeda juga disebut data citra satelit multi temporal (Fanni 2014). Citra yang digunakan diklasifikasi menjadi enam kelas yaitu kelas awan, sungai, pertanian, perkebunan, hutan, dan pemukiman. Pemasukan awan dalam klas tutupan lahan disebabkan terdapat bagian pada citra yang digunakan tertutupi awan. Oleh sebab tertutup awan, tutupan lahan yang tertutupi menjadi tidak terdefinisi. Metode klasifikasi yang digunakan yaitu klasifikasi terbimbing maximum likelihood. Masing-masing kelas tutupan lahan dibuatkan training area atau sampelnya dan dikelompokkan dengan nilai piksel yang sama. Gambar 3 merupakan peta tutupan lahan tahun 2003, 2013, dan 2018.

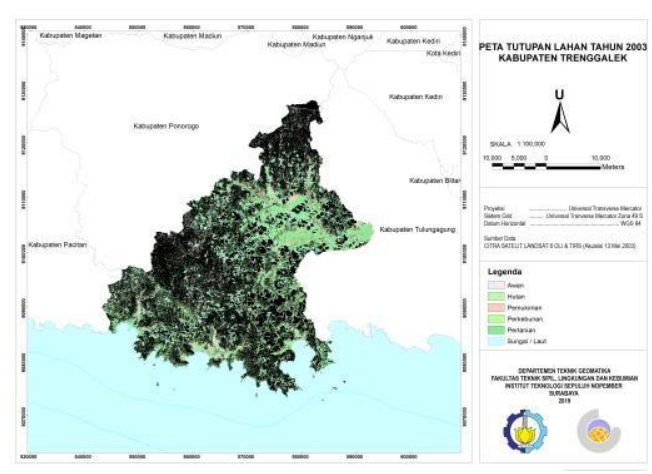

Gambar 3. Peta Tutupan Lahan Tahun 2003 (Sumber: Hasil Pengolahan)

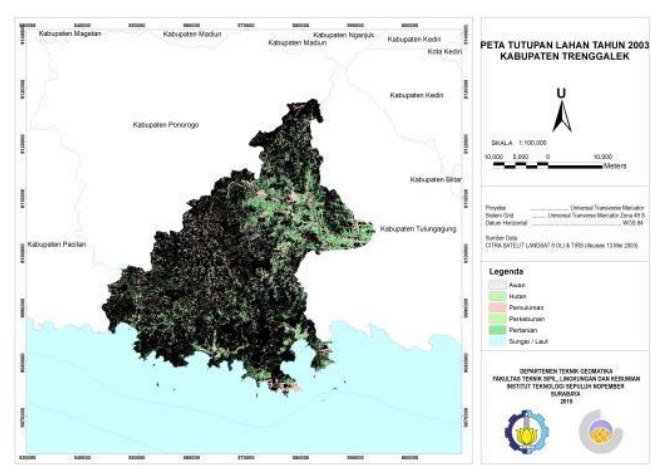

Gambar 4. Peta Tutupan Lahan Tahun 2013 (Sumber: Hasil Pengolahan) 


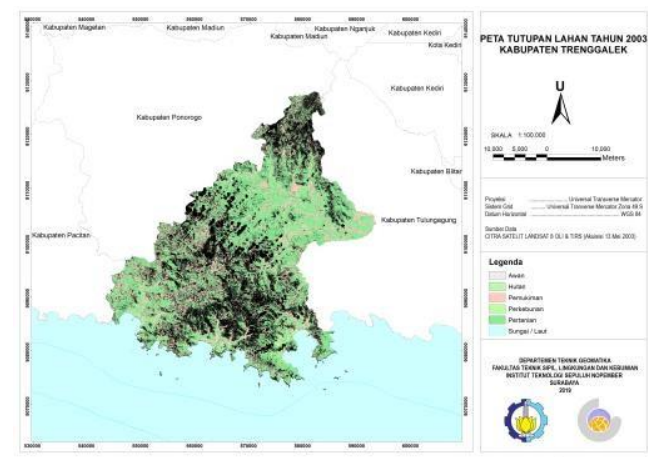

Gambar 5. Peta Tutupan Lahan Tahun 2018 (Sumber: Hasil Pengolahan)

Dilakukan perhitungan perubahan masing-masing kelas tutupan lahan pada rentang tahun 2003-2013, dan 2013-2018. Hasil perhitungan perubahan tutupan lahan disajikan dalam tabel 2. Nilai positif menunjukkan adanya penambahan luasan tutupan lahan. Nilai negative menunjukkan adanya pengurangan luasan kelas tutupan lahan. Perubahan tersebut dijumlah dengan menghiraukan nilai positif maupun negatif dari nilai perubahan. Total perubahan tutupan lahan dari tahun 2003 sampai 2013 yaitu 48277,34 Ha. Total perubahan tutupan lahan dari tahun 2013 sampai 2018 yaitu 101092,8 Ha.

Tabel 2. Perubahan Tutupan Lahan (Sumber: Hasil

\begin{tabular}{lcl}
\multicolumn{3}{c}{ Pengolahan) } \\
\hline Tutupan lahan & $2003-2013$ & $2013-2018$ \\
\hline awan & 5773,52 & $-6931,77$ \\
sungai & $-7706,81$ & $-1318,03$ \\
hutan & 11002,6 & $-42296,6$ \\
pertanian & $-5017,6$ & 37913 \\
pemukiman & 7362,52 & 10551,1 \\
perkebunan & $-11414,3$ & 2082,285 \\
Total & 48277,34 & 101092,8
\end{tabular}

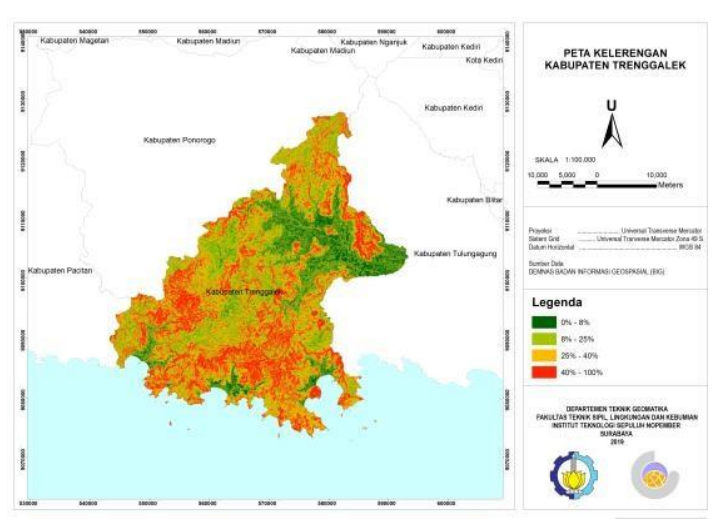

Gambar 6. Peta Kelerengan (Sumber: Hasil Pengolahan)
Peta kelerengan dibuat dengan menggunakan perangkat lunak sistem informasi geografis. Sebelum melakukan operasi pembuatan peta kelerengan, delapan data yang digunakan digabungkan/mosaic terlebih dahulu. Proses mosaic ini dilakukan untuk mendapatkan satu data DEM yang melingkupi seluruh wilayah studi kasus. Selanjutnya pembuatan peta kelerengan dengan pengaturan nilai kelerengan dalam persen (\%). Untuk membuat peta kelerengan dengan satuan kelerengan dalam persen (\%), sistem koordinat horizontalnya diproyeksikan dalam sistem koordinat UTM dengan zona 49 di sebelah selatan garis khatulistiwa. Zona ini sesuai dengan zona lokasi Kabupaten Trenggalek yang merupakan lokasi data DEMNAS yang digunakan.
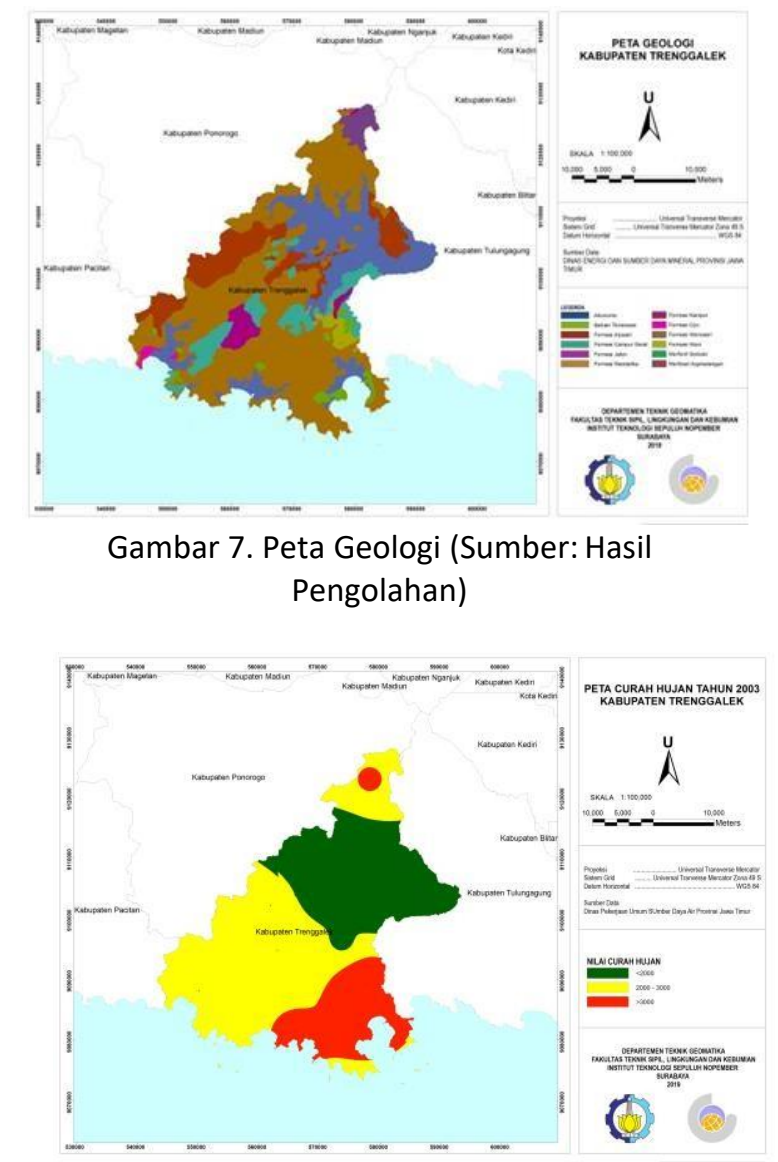

Gambar 8. Peta Curah Hujan Tahun 2003 (Sumber: Hasil Pengolahan) 


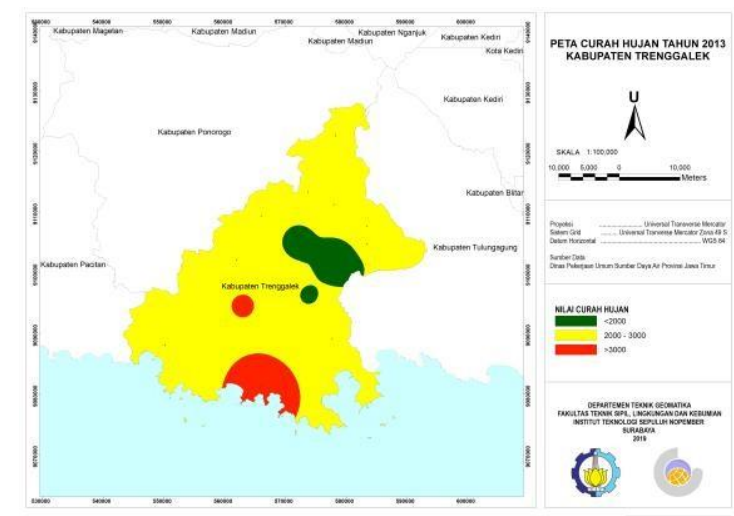

Gambar 9. Peta Curah Hujan Tahun 2013 (Sumber: Hasil Pengolahan)

Proses interpolasi nilai curah hujan dilakukan dengan menggunakan perangkat lunak sistem informasi geografis. Nilai curah hujan yang digunakan yaitu nilai curah hujan tahunan di wilayah studi kasus. Metode interpolasi yang digunakan adalah metode IDW (Inverse Distance Weighted) dengan menghitung nilai berdasarkan kebalikan jarak antar titik. Hasil peta curah hujan diklasifikasi ke dalam tiga kelas interval nilai curah hujan. Kelas pertama untuk nilai curah hujan tahunan di bawah $2000 \mathrm{~mm}$. Kelas kedua untuk nilai curah hujan $2000 \mathrm{~mm}$ sampai 3000 $\mathrm{mm}$. Untuk nilai curah hujan tahunan diatas 3000 $\mathrm{mm}$ dimasukkan dalam kelas ketiga.

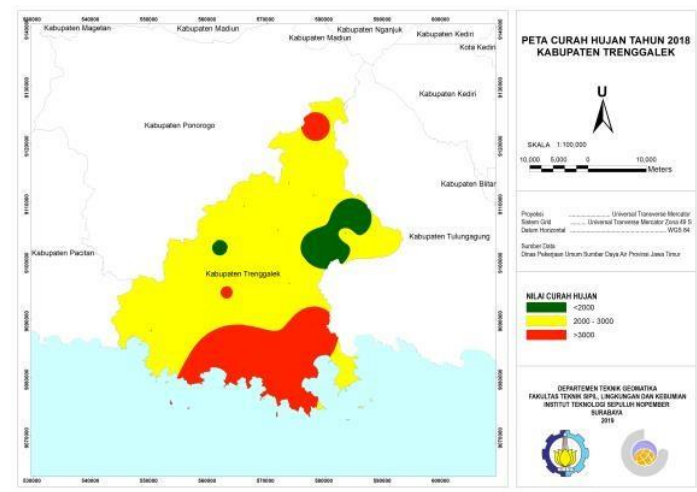

Gambar 10. Peta Curah Hujan Tahun 2018 (Sumber: Hasil Pengolahan)

\section{Pembobotan Parameter Potensi Longsor}

Peta potensi longsor merupakan hasil dari proses analisis spasial dan pembobotan empat faktor potensi longsor. Analisis spasial yang digunakan yaitu overlay union. Proses overlay union dilakukan dengan menggabungkan seluruh data spasial maupun atribut dari setiap data faktor potensi longsor. hasil dari proses ini yaitu gabungan data spasial dan atribut dari empat data faktor potensi longsor. selanjutnya dilakukan pembobotan untuk menghasilkan indeks potensi longsor. Kedua proses tersebut dilakukan dengan menggunakan perangkat lunak sistem informasi geografis.

Tabel 3. Interval nilai tingkat potensi longsor (Sumber:

\begin{tabular}{cc}
\multicolumn{2}{c}{ Hasil Pengolahan) } \\
\hline Interval nilai & Tingkat Potensi \\
\hline $0-0,9$ & Rendah \\
$1-1,8$ & Menengah \\
$>1,8$ & Tinggi \\
\hline
\end{tabular}

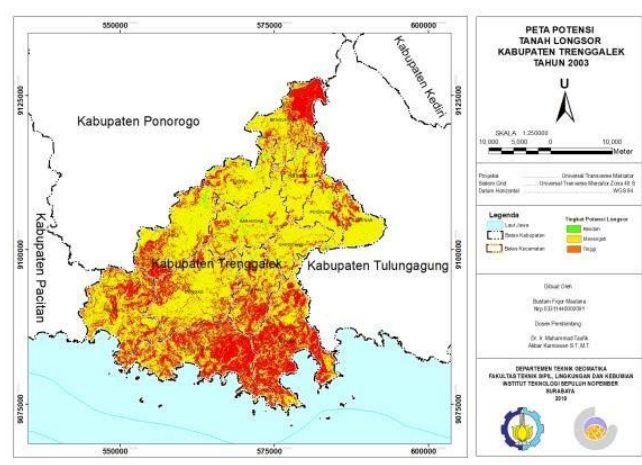

Gambar 11. Peta Potensi Longsor Tahun 2003 (Sumber: Hasil Pengolahan)

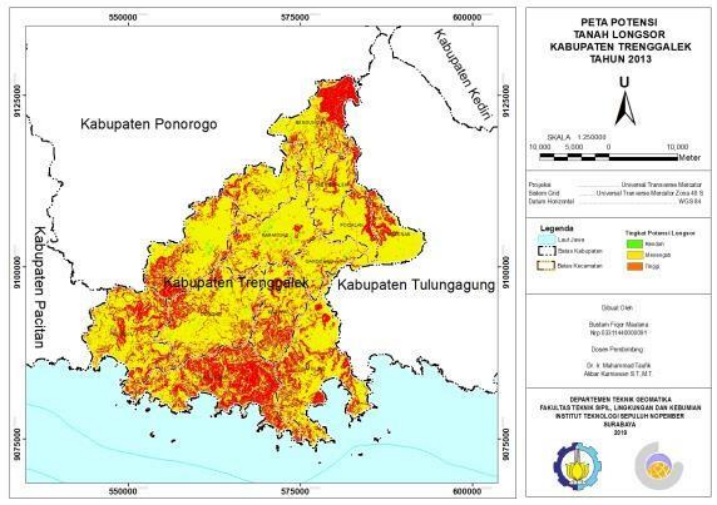

Gambar 12. Peta Potensi Longsor Tahun 2013 (Sumber: Hasil Pengolahan)

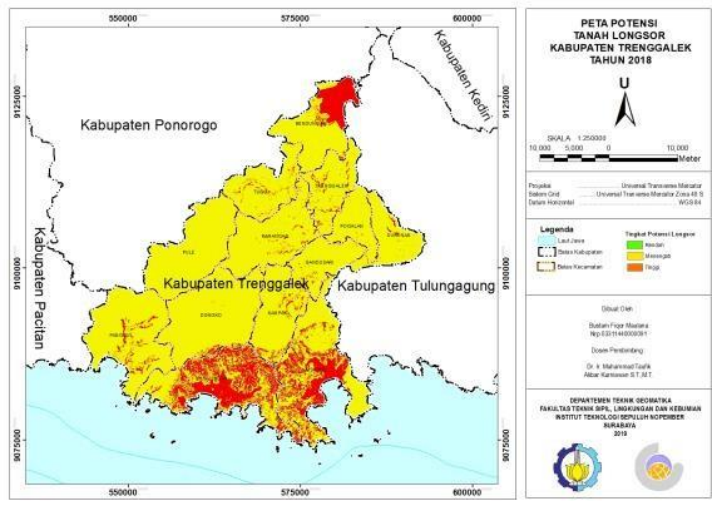

Gambar 13. Peta Potensi Longsor Tahun 2018 (Sumber: Hasil Pengolahan) 
Peta potensi longsor kemudian divalidasi menggunakan data kejadian bencana longsor. karena data kejadian longsor yang tersedia tahun 2014 ke atas, maka peta potensi longsor yang divalidasi terbatas pada peta potensi longsor tahun 2018. Data kejadian longsor yang digunakan berupa data titik koordinat.

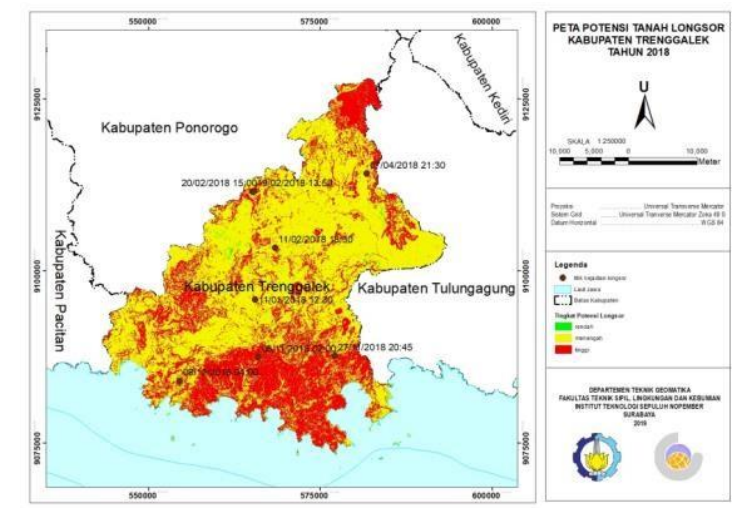

Gambar 14. Validasi Peta Potensi Longsor Tahun 2018 (Sumber: Hasil Pengolahan)

\section{Perubahan Daerah Potensi Longsor}

Zona tingkat potensi longsor dari masingmasing peta potensi longsor dihitung luasnya. Besar luasan dari masing-masing zona tersebut kemudian dihitung perbedaannya. Nilai perbedaan berupa negatif menunjukkan adanya pengurangan luasan. Nilai perbedaan dalam positif menunjukkan adanya penambahan luasan. Angka perubahan luasan dari masing-masing zona potensi longsor kemudian dijumlah dengan mengabaikan nilai negatif maupun postifnya. Hasil perhitungan perbedaan luasan tersebut disajikan dalam tabel 4.

Tabel 4. Perubahan Daerah potensi longsor (Sumber: Hasil Pengolahan)

\begin{tabular}{c|cc}
\hline \multirow{2}{*}{ Tingkat potensi longsor } & \multicolumn{2}{|c}{ Luas (Ha) } \\
\cline { 2 - 3 } & $2003-2013$ & $2013-2018$ \\
\hline Rendah & $-155,9294$ & $-25,10372$ \\
Menengah & 5040,572 & $-7416,18$ \\
tinggi & $-4885,749$ & 7441,489 \\
Total perubahan & 10082,25 & 14882,77 \\
\hline
\end{tabular}

\section{Analisis Korelasi}

Dilakukan perhitungan korelasi antara perubahan tutupan lahan (tabel 2) dengan perubahan potensi longsor (tabel 4). Hasil dari perhitungan korelasi yaitu positif satu. Angka menunjukkan adanya korelasi positif yang kuat. Hal ini menunjukkan semakin besar perubahan tutupan lahan maka semakin besar perubahan potensi longsor. tabel perhitungan korelasi disajikan dalam tabel 5 .

Tabel 5. Korelasi Perubahan Tutupan Lahan dengan Perubahan Daerah potensi longsor (Sumber: Hasil Pengolahan)

\begin{tabular}{|c|c|c|c|c|c|c|c|}
\hline $\begin{array}{l}\text { Beda } \\
\text { tahun }\end{array}$ & $\begin{array}{c}\mathrm{X} \\
\text { (perubahan } \\
\text { potensi } \\
\text { longsor) } \\
\end{array}$ & $\begin{array}{c}\mathrm{Y} \\
\text { (perubahan } \\
\text { tutupan } \\
\text { lahan) } \\
\end{array}$ & $x(X-X)$ & y (Y-Y) & $x y$ & $x^{2}$ & $y^{2}$ \\
\hline $\begin{array}{l}2003- \\
2013\end{array}$ & 10082,25 & 48277,34 & 56,45 & $-35385,40$ & $-1997473,71$ & 3186,50 & 1252127029 \\
\hline $\begin{array}{l}2013- \\
2018\end{array}$ & 14882,77 & 101092,80 & 4856,97 & 17430,04 & 84657207,11 & 23590169 & 303806329,30 \\
\hline $\begin{array}{l}\text { Rata- } \\
\text { rata } \\
\text { (y/ (I) }\end{array}$ & 12482,51 & 74685,06 & & Total & 126770863,10 & 11522506 & 1394735774 \\
\hline \multicolumn{8}{|c|}{ Koefisien Korelasi $=+1$} \\
\hline
\end{tabular}

\section{KESIMPULAN}

Berdasarkan hasil dan analisis yang telah diuraikan, maka kesimpulan yang didapatkan dari penelitian ini adalah:

1. Dihasilkan tiga peta potensi longsor Kabupaten Trenggalek. Nilai indeks potensi longsor diklasifikasi dalam tiga tingkat potensi longsor. Kelas pertama dengan tingkat potensi longsor rendah memiliki interval nilai indeks potensi longsor antara $0-0,9$. Kelas kedua dengan tingkat potensi longsor menengah memiliki interval nilai indeks potensi longsor antara 1 - 1,8. Dan terakhir Kelas ketiga dengan tingkat potensi longsor tinggi memiliki interval nilai indeks potensi longsor diatas 1,8 . Hasil validasi peta potensi longsor tahun

2018 menunjukkan titik kejadian tanah longsor tejadi di wilayah dengan tingkat potensi tinggi.

2. Hasil perhitungan koefisien korelasi antara perubahan luasan tutupan lahan dan perubahan luasan peta potensi longsor menunjukkan adanya korelasi yang kuat dengan nilai +1

Adapun beberapa saran yang bisa disampaikan dari penelitian ini adalah:

1. Untuk penelitian selanjutnya, dapat digunakan berbagai rumus transformasi pada saat proses rektifikasi citra untuk mendapatkan hasil yang paling optimal.

2. Pola sebaran titik kontrol tanah sebaiknya 
dilakukan merata, pada perimeter citra atau area terluar citra, dan pada area pertampalan citra.

3. Untuk penelitian selanjutnya, dapat digunakan jumlah GCP yang sama tetapi dengan pengambilan metode yang berbeda untuk menganalisis ketelitian geometri citra yang dihasilkan.

\section{UCAPAN TERIMA KASIH}

Penulis V.P.P mengucapkan terima kasih kepada Bapak Dr. Ir. Muhammad Taufik dan Bapak Akbar Kurniawan S.T., M.T. atas kesediaannya untuk membimbing dalam penelitian ini. Serta terima kasih kepada Dinas PU SDA Provinsi Jawa Timur, Dinas ESDM Provinsi Jawa Timur, dan BPBD Provinsi Jawa Timur yang telah memberikan data penelitian ini.

\section{DAFTAR PUSTAKA}

Arifin S, Carolila I, dan Winarso C. 2006. Implementasi Penginderaan Jauh dan SIG untuk Inventarisasi Daerah Rawan Bencana Longsor (Propinsi Lampung). Jakarta : LAPAN.

BPBD Kabupaten Trenggalek. 2019. Infografis Kejadian Bencana 2018. http://bpbd.trenggalekkab.go.id/index.php/in fo-bencana/255-infografis-kejadian-bencanatahun-2018, (Diakses pada tanggal 28 Januari
2019).

BPS Kabupaten Trenggalek. 2018. Kabupaten Trenggalek Dalam Angka Tahun 2018. Trenggalek : BPS.

Fahlevi, Rizha. 2018. Analisis Potensi Wilayah Tanah Longsor di Kawasan Lereng Gunung Wilis dengan Mengggunakan Data DEM dan Terrasar-X. Surabaya : Institut Teknologi Sepuluh Nopember.

Fanni, A. N. M. 2014. Kajian Perubahan Tutupan Lahan Daerah Aliran Sungai Brantas Menggunakan Citra Satelit Multitemporal (Studi Kasus : Kali Porong, Kabupaten Sidoarjo). Surabaya : Institut Teknologi Sepuluh Nopember.

Khoiri M., Jaelani L. M., dan Widodo A. 2017. Landslides Hazard Mapping Using Remote Sensing Data in Ponorogo Regency, East Java. Internet Journal of Society for Social Management Systems:11.

Maryantika N., Jaelani L. M., dan Setiyoko A. 2011. Analisa Perubahan Vegetasi Ditinjau Dari Tingkat Ketinggian dan Kemiringan Lahan Menggunakan Citra Satelit Landsat dan SPOT4 (Studi Kasus Kabupaten Pasuruan). GEOID Vol. $07: 1$.

Peraturan Kepala BNPB No. 2 Tahun 2012 Tentang Pedoman Umum Pengkajian Risiko Bencana.

PVMBG. 2005. "Pengenalan Gerakan Tanah." ESDM. https://www.esdm.go.id/assets/media/cocon te/P engenalan_Gerakan_Tanah.pdf.

Spiegel M. R., 1975. Schaum Outline of Theory and Problems of Probability and Statistics SI (Metric) Edition. Singapore : McGraw-Hill Inc. 